\title{
Efficacy of some plant oils against two stored product insects
}

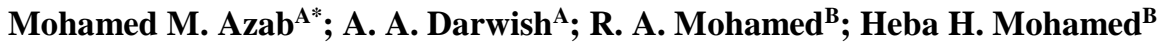 \\ APlant Protection Department, Faculty of Agric., Benha Univ.,Qalubia, Egypt. \\ ${ }^{B}$ Plant Protection Research Institute, Agric. Res. Center, Ministry of Agric., Giza, Egypt. \\ * Corresponding author: mohamed.azab@fagr.bu.edu.eg
}

\begin{abstract}
To investigate the insecticidal activity of marjoram, caraway and worm wood oils against the adults of Sitophilus oryzae (L.) (Curculionidae, Coleoptera) and the active and diapausing larvae of khapera beetle Trogoderema granarium (Everts) laboratory bioassay tests were conducted, at four to five concentrations of each plant oil, of 21 days under 30 and $20 \pm 1{ }^{\circ} \mathrm{C}$. The results indicated that the mortality of tested insects increased with increasing the plant oil concentration, exposure period and temperature, where the complete mortality of $S$. oryzae adults was obtained at 1.5 and $1 \%(\mathrm{v} / \mathrm{w})$ of the three tested oils, after 21 days exposure periods at $30^{\circ} \mathrm{C}$. Data also revealed that at $20^{\circ} \mathrm{C}$, the worm wood oil was the most toxic for the studied insects, and it gave $\mathrm{LC}_{50 \mathrm{~s}}$ of $2.41,2.90$ and $0.21 \%$ for active and diapausing larvae of $T$. granarium (after 14 days exposure period) and for the adults of $S$. oryzae (after 3 days exposure period), respectively. Caraway oil was the most toxic at $30^{\circ} \mathrm{C}$ against the active and diapausing larvae of $T$. granarium. The adults of $S$. oryzae were more sensitive to investigated plant oils than active and diapausing larvae of $T$ granarium. It can be concluded that marjoram, caraway and worm wood oils have a toxic activity against the two stored-product insects, $S$. oryzae and T. granarium.
\end{abstract}

Key words: majoram, caraway, worm wood, insecticidal activity, Sitophilus oryzae, Trogoderema granarium

\section{Introduction}

Insect pests cause damage to stored grains and processed products by reducing their dry weight and nutritional value (Dubeyet al., 2008). Additionally, insect infestation-induced changes in the storage environment may cause warm moist "hotspots" that provide suitable conditions for growth fungi that cause further losses (Jacobson, 1982).

Although, methyl bromide and phosphine are effective and available, there is a global concern about their negative effects, such as ozone depletion, environmental pollution, toxicity to non-target organisms, pest resistance, and pesticide residues (Hansen and Jensen, 2002; Benhalima et al., 2004; Bughio and Wilkins, 2004). Thus, there is an urgent need to develop safe alternatives for stored-grain pest control.

One of possible alternatives to synthetic pesticides is the screening of plants in search for alternatives pest control agents such as extracts of plant leaves, seeds, flowers, plant oils etc., in order to overcome and reduce the danger of pollution occurring from the wide use of pesticides in controlling the pests. It is hoped that such agents would be more degradable in nature and with less adverse effects on mammals than the conventional synthetic insecticides (EL-Lakwah et al., 1997). Studies on plant extracts, dusts and plant oils as pest control agents against stored product pests gave promising results (Yadav, 1984; Jaibal et al., 1984; Su, 1985 and 1989; Javier et al., 1986; Sighamony et al., 1986; Darwish, 1992; EL-Lakwah et al., 1992, 1993, 1994, 1996, 1997 and 2002; Halawa, 1998; Boff et al., 2006).

Oils isolated from plants can play an important role in stored grain protection and reduce the risks associated with the use of synthetic insecticides (Hernandez et al., 2015). Different concentrations from eight plant oils, lemon grass, pinussylvestris, parsley, fennel, geranium, peppermint, pittegra in and sweet basil were used for protection of cowpea and chickpea seeds from infestation by Callosobruchus maculatus (Hassan et al., 2013).

The aim of this work was to evaluate the effectiveness of plant oils of marjoram, caraway and worm wood against the adults of $S$. oryzae and active and diapausing larvae of $T$. granarium.

\section{Materials and Methods}

Insects

Two stored product insect species, namely the rice weevil, Sitophilus oryzae (L.) (Curculionidae, Coleoptera) and khapera beetle Trogoderema granarium (Everts) were obtained from the existing culture in the stored product pests Laboratory at the Plant Protection Department, Faculty of Agriculture, Benha University.

\section{Rearing technique}

The insects were reared in glass jars (approx. $500 \mathrm{ml}$ ) containing about $200 \mathrm{~g}$ of sterilized and conditioned wheat grains. The glass jars were 
covered with muslin. Insect cultures were kept under controlled conditions of $30 \pm 1^{\circ} \mathrm{C}$ and $65 \pm 5 \%$ R.H. at the rearing room of the laboratory. Wheat grains were treated by freezing at $-18^{\circ} \mathrm{C}$ for 2 weeks before application to eliminate any possible infestation by any insect species. The moisture content of the grains was around $14 \%$. Around 300 adults o S. oryzae (1-2 weeks old) were introduced into the jars for laying eggs and then kept at $30 \pm 1^{\circ} \mathrm{C}$ and $65 \pm 5 \%$ R.H. Three days later, all insects were separated from the food, and the jars were kept again at the controlled conditions in the rearing room. This procedure was repeated several times in order to obtain large number of the adults needed to carry out the experiments during this study. In case of $T$. granarium about 200 adults 2-5 days old were added to the wheat grains inside the jars for laying eggs under controlled conditions. T. granarium active $\left(3^{\text {rd }}\right.$ and $4^{\text {th }}$ larval instar) and diapausing larvae were taken for the tests, the diapausing (quiescent) larvae were collected from roll of paper, which had been placed on the top of the culture media.

Batches of 30 active and diapausing larvae of $T$. granarium and 30adults of $S$. oryzae were used in all experiments.

\section{Tested temperatures}

All experiments were conducted under two temperatures 30 and $20 \pm 1^{\circ} \mathrm{C}$ and $65 \pm 5 \%$.

\section{Plant oils used \\ Majorana hortensis, Carumcarvi and Matricari achamomillaoils were bought form Guvadant Swaziland Company. \\ Majoran ahortensis (Marjoram)}

The major components in the oils are ar-curcumene (25\%), $\beta$-caryophyllene (13\%) and caryophyllene epoxide (7\%).

\section{Carum carvi (Caraway)}

The major components of caraway oil are carfoon and liemonin.

\section{Matricar a chamomilla (Worm wood)}

The major component of worm wood oil is camazolen.

\section{Bioassay test}

Twenty milliliters each oil were diluted with $50 \mathrm{ml}$ acetone to obtain $40 \%(\mathrm{v} / \mathrm{v})$ stock concentration which diluted to obtain 40, 35, 30, 25, 20, 15, 10, 5, 2.5 and $1.25 \%(\mathrm{v} / \mathrm{v})$ concentrations. From each concentration, $1 \mathrm{ml}$ was taken and added to $10 \mathrm{~g}$ wheat grains to obtain $4,3.5,3,2.5,2,1.5,1,0.5$, 0.25 and $0.125 \%(\mathrm{v} / \mathrm{w})$ concentrations $(4,3.5,3$, 2.5 and $2 \%$ in case of diapausing larvae of $T$. granarium, 3.5, 3, 2.5 and $2 \%$ in case of active larvae of $T$. granariumand $1.5,1,0.5,0.25$ and $0.125 \%$ in case of adults of $S$. oryzae). Thirty insects were added to each treatment and incubated at 30 and $20 \pm 1{ }^{\circ} \mathrm{C}$. Three replicates were used for each treatment. For control only acetone was used for food treatment. Insect mortality was calculated after 1, 2, $3,5,7,14$ and 21 days from initial treatment to calculate the lethal concentration and the lethal time of the oils.

\section{Data analysis}

Data were analysed using probit analysis models (Finney, 1971) using a computer program of Noack and Reichmuth (1978).

\section{Results and Discussion}

Effect of the tested plant oils against the adult mortality of Sitophilu soryzae and the larvae of Khapera beetle Trogoderma granarium at 30 and $20 \pm 1^{\circ} \mathrm{C}$ and $65 \pm 5 \%$ R.H.

\subsection{S. oryzae adults \\ 1.1.1. Marjoram oil}

The data of the effect of marjoram oil on the adult mortality of $S$. oryzae at 30 and $20 \pm 1^{\circ} \mathrm{C}$ were presented in Fig (1-5). The results revealed that the mortality increased by increasing the plant oil concentration, period of exposure and temperature. At marjoram oil concentration of $1.5 \%(\mathrm{v} / \mathrm{w})$ the adult mortality of $S$. oryzae, after 1 day exposure period was 60.1 and 50.1 at 30 and $20^{\circ} \mathrm{C}$, respectively. While, the mortality increased after 21 days post treatment to 100 and $80.1 \%$ at 30 and $20^{\circ} \mathrm{C}$, respectively. At concentration $1 \%(\mathrm{v} / \mathrm{w})$ the mortality was 53.3 and $45.5 \%$ after 1 day exposure period and increased after 21 days post treatment to 100 and $75.5 \%$ at 30 and $20^{\circ} \mathrm{C}$, respectively. At concentration $0.5 \%(\mathrm{v} / \mathrm{w})$ the mortality was 41.1 and $40.1 \%$ after 1 day exposure and increased after 21 days exposure period to 85.5 and $65.1 \%$ post treatment at 30 and $20^{\circ} \mathrm{C}$, respectively. At concentration $0.25 \%(\mathrm{v} / \mathrm{w})$ the mortality was 36.6 and $33.3 \%$ after 1 day exposure time and increased after 21 days post treatment to 82.2 and $61.1 \%$ at 30 and $20^{\circ} \mathrm{C}$, respectively. At concentration $0.125 \%$ (v/w) the mortality was 28.8 and $20.1 \%$ after 1 day exposure and increased after 21 days of the treatment to 67.7 and $58.5 \%$ at 30 and $20^{\circ} \mathrm{C}$, respectively.

\subsubsection{Caraway oil}

The results of the effect of caraway oil on the adult mortality of $S$. oryzae at 30 and $20 \pm 1{ }^{\circ} \mathrm{C}$ were presented in Fig (1-5). The data showed that the mortality increased by increasing the plant oil concentration, period of exposure and temperature. At caraway oil concentration of $1.5 \%(\mathrm{v} / \mathrm{w})$ the adult mortality of $S$. oryzae, after 1 day exposure period was 63.3 and 55.5 at 30 and $20^{\circ} \mathrm{C}$, respectively. While, the mortality increased after 21 days post treatment to 100 and $85.5 \%$ at 30 and $20^{\circ} \mathrm{C}$, respectively. At concentration $1 \%(\mathrm{v} / \mathrm{w})$ the mortality was 60.1 and $50.1 \%$ after 1 day exposure period and increased after 21 days post treatment to 100 and $85.5 \%$ at 30 and $20^{\circ} \mathrm{C}$, respectively. At concentration $0.5 \%(\mathrm{v} / \mathrm{w})$ the mortality was 45.5 and $42.2 \%$ after 1 day exposure and increased after 21 days exposure 
period to 90.1 and $75.5 \%$ post treatment at 30 and $20^{\circ} \mathrm{C}$, respectively. At concentration $0.25 \%(\mathrm{v} / \mathrm{w})$ the mortality was 50.1 and $40.1 \%$ after 1 day exposure time and increased after 21 days post treatment to 85.5 and $70.1 \%$ at 30 and $20^{\circ} \mathrm{C}$, respectively. At concentration $0.125 \%(\mathrm{v} / \mathrm{w})$ the mortality was 41.1 and $33.3 \%$ after 1 day exposure and increased after 21days of the treatment to 75.5 and $68.1 \%$ at 30 and $20^{\circ} \mathrm{C}$, respectively.

\subsubsection{Worm wood oil}

The data of the effect of worm wood oil on the adult mortality of $S$. oryzae at 30 and $20 \pm 1^{\circ} \mathrm{C}$ were presented in Fig (1-5). The results indicated that the mortality increased by increasing the plant oil concentration, period of exposure and temperature. At worm wood oil concentration of $1.5 \%(\mathrm{v} / \mathrm{w})$ the adult mortality of $S$. oryzae, after 1 day exposure period was 65.5 and 60.1 at 30 and $20^{\circ} \mathrm{C}$, respectively. While, the mortality increased after 21 days post treatment to 100 and $90.1 \%$ at 30 and $20^{\circ} \mathrm{C}$, respectively. At concentration $1 \%(\mathrm{v} / \mathrm{w})$ the mortality was 63.3 and $55.5 \%$ after 1 day exposure period and increased after 21 days post treatment to 100 and $85.5 \%$ at 30 and $20^{\circ} \mathrm{C}$, respectively. At concentration $0.5 \%(\mathrm{v} / \mathrm{w})$ the mortality was 64.6 and $43.3 \%$ after 1 day exposure and increased after 21 days exposure period to 91.1 and $77.1 \%$ post treatment at 30 and $20^{\circ} \mathrm{C}$, respectively. At concentration $0.25 \%(\mathrm{v} / \mathrm{w})$ the mortality was 52.2 and $45.5 \%$ after 1 day exposure time and increased after 21 days post treatment to 90.1 and $75.5 \%$ at 30 and $20^{\circ} \mathrm{C}$, respectively. At concentration $0.125 \%$ (v/w) the mortality was 42.2 and $35.5 \%$ after 1 day exposure and increased after 21 days of the treatment to 80.1 and $72.2 \%$ at 30 and $20^{\circ} \mathrm{C}$, respectively.

\section{2. $T$. granarium active larvae}

\subsubsection{Marjoram oil}

The results of the effect of marjoram oil on the larvae mortality of active larvae of $T$. granarium at 30 and $20 \pm 1^{\circ} \mathrm{C}$ were presented in Fig (6-9). The data showed that the mortality increased by increasing the plant oil concentration, period of exposure and temperature. At marjoram oil concentration of $3.5 \%$ (v/w) the active larvae mortality of $T$. granarium, after 1 day exposure period was 15.7 and 7.7 at 30 and $20^{\circ} \mathrm{C}$, respectively. Whereas, the mortality increased after 21 days post treatment to 92.2 and $70.1 \%$ at 30 and $20^{\circ} \mathrm{C}$, respectively. At concentration $3 \%(\mathrm{v} / \mathrm{w})$ the mortality was 13.3 and $5.7 \%$ after 1 day exposure period and increased after 21 days post treatment to 91.1 and $65.5 \%$ at 30 and $20^{\circ} \mathrm{C}$, respectively. At concentration $2.5 \% \quad(\mathrm{v} / \mathrm{w})$ the mortality was 6.5 and $2.3 \%$ after 1 day exposure and increased after 21 days exposure period to 85.5 and $54.3 \%$ post treatment at 30 and $20^{\circ} \mathrm{C}$, respectively. At concentration $2 \%(\mathrm{v} / \mathrm{w})$ the mortality was 4.3 and $1.2 \%$ after 1 day exposure time and increased after 21 days post treatment to 80.1 and $20 \%$ at 30 and $20^{\circ} \mathrm{C}$, respectively. At concentration $1.5 \%(\mathrm{v} / \mathrm{w})$ the mortality was 4.1 and $1.1 \%$ after 1 day exposure and increased after 21days of the treatment to 70.1 and $18.2 \%$ at 30 and $20^{\circ} \mathrm{C}$, respectively.

\subsubsection{Caraway oil}

The data of the effect of caraway oil on the larvae mortality of active larvae of $T$. granarium at 30 and $20 \pm 1^{\circ} \mathrm{C}$ were presented in Fig (6-9). The results indicated that the mortality increased by increasing the plant oil concentration, period of exposure and temperature. At caraway oil concentration of $3.5 \%$ (v/w) the active larvae mortality of $T$. granarium, after 1 day exposure period was 17.1 and 7.8 at 30 and $20^{\circ} \mathrm{C}$, respectively. While, the mortality increased after 21 days post treatment to 95.5 and $77.7 \%$ at 30 and $20^{\circ} \mathrm{C}$, respectively. At concentration $3 \%(\mathrm{v} / \mathrm{w})$ the mortality was 13.5 and $6.6 \%$ after 1 day exposure period and increased after 21 days post treatment to 93.3 and $66.6 \%$ at 30 and $20^{\circ} \mathrm{C}$, respectively. At concentration $2.5 \% \quad(\mathrm{v} / \mathrm{w})$ the mortality was 10.1 and $5.5 \%$ after 1 day exposure and increased after 21 days exposure period to 86.5 and $60.1 \%$ post treatment at 30 and $20^{\circ} \mathrm{C}$, respectively. At concentration $2 \%(\mathrm{v} / \mathrm{w})$ the mortality was 6.1 and $4.1 \%$ after 1 day exposure time and increased after 21 days post treatment to 82.2 and $33.3 \%$ at 30 and $20^{\circ} \mathrm{C}$, respectively. At concentration $1.5 \%(\mathrm{v} / \mathrm{w})$ the mortality was 5.5 and $3.5 \%$ after 1 day exposure and increased after 21days of the treatment to 75.5 and $30.1 \%$ at 30 and $20^{\circ} \mathrm{C}$, respectively.

\subsubsection{Worm wood oil}

The results of the effect of worm wood oil on the larvae mortality of active larvae of $T$. granarium at 30 and $20 \pm 1^{\circ} \mathrm{C}$ were presented in Fig (6-9). The data showed that the mortality increased by increasing the plant oil concentration, period of exposure and temperature. At worm wood oil concentration of $3.5 \%(\mathrm{v} / \mathrm{w})$ the active larvae mortality of $T$. granarium, after 1 day exposure period was 18.2 and 8.1 at 30 and $20^{\circ} \mathrm{C}$, respectively. While, the mortality increased after 21 days post treatment to 96.6 and $78.8 \%$ at 30 and $20^{\circ} \mathrm{C}$, respectively. At concentration $3 \%(\mathrm{v} / \mathrm{w})$ the mortality was 14.5 and $7.2 \%$ after 1 day exposure period and increased after 21 days post treatment to 94.1 and $68.2 \%$ at 30 and $20^{\circ} \mathrm{C}$, respectively. At concentration $2.5 \% \quad(\mathrm{v} / \mathrm{w})$ the mortality was 11.1 and $6.3 \%$ after 1 day exposure and increased after 21 days exposure period to 90.1 and $62.2 \%$ post treatment at 30 and $20^{\circ} \mathrm{C}$, respectively. At concentration $2 \%(\mathrm{v} / \mathrm{w})$ the mortality was 7.1 and $5.5 \%$ after 1 day exposure time and increased after 21 days post treatment to 85.5 and $45.5 \%$ at 30 and $20^{\circ} \mathrm{C}$, respectively. At concentration $1.5 \%(\mathrm{v} / \mathrm{w})$ the mortality was 6.5 and $5.1 \%$ after 1 day exposure and increased after 21 days of the treatment to 80.1 and $40.1 \%$ at 30 and $20^{\circ} \mathrm{C}$, respectively.

\section{3. $T$. granarium diapausing larvae 1.3.1. Marjoram oil}


The data of the effect of marjoram oil on the larvae mortality of diapausing larvae of $T$. granarium at 30 and $20 \pm 1^{\circ} \mathrm{C}$ were presented in Fig (10-14). The results revealed that the mortality increased by increasing the plant oil concentration, period of exposure and temperature. At marjoram oil concentration of $4 \%(\mathrm{v} / \mathrm{w})$ the diapausing larvae mortality of $T$. granarium, after 1 day exposure period was 11.1 and 6.1 at 30 and $20^{\circ} \mathrm{C}$, respectively. While, the mortality increased after 21 days post treatment to 72.2 and $69.6 \%$ at 30 and $20^{\circ} \mathrm{C}$, respectively. At concentration $3.5 \% \quad(\mathrm{v} / \mathrm{w})$ the mortality was 10.1 and $5.7 \%$ after 1 day exposure period and increased after 21 days post treatment to 70.1 and $66.6 \%$ at 30 and $20^{\circ} \mathrm{C}$, respectively. At concentration $3 \%(\mathrm{v} / \mathrm{w})$ the mortality was 6.6 and $4.1 \%$ after 1 day exposure and increased after 21 days exposure period to 65.5 and $55.5 \%$ post treatment at 30 and $20^{\circ} \mathrm{C}$, respectively. At concentration $2.5 \%(\mathrm{v} / \mathrm{w})$ the mortality was 5.1 and $3.2 \%$ after 1 day exposure time and increased after 21 days post treatment to 50.1 and $45.5 \%$ at 30 and $20^{\circ} \mathrm{C}$, respectively. At concentration $2 \%(\mathrm{v} / \mathrm{w})$ the mortality was 4.2 and $2.1 \%$ after 1 day exposure and increased after 21 days of the treatment to 45.5 and $18.1 \%$ at 30 and $20^{\circ} \mathrm{C}$, respectively.

\subsubsection{Caraway oil}

The results of the effect of caraway oil on the larvae mortality of diapausing larvae of $T$. granarium at 30 and $20 \pm 1^{\circ} \mathrm{C}$ were presented in Fig (10-14). Data showed that the mortality increased by increasing the plant oil concentration, period of exposure and temperature. At caraway oil concentration of $4 \%$ (v/w) the diapausing larvae mortality of $T$. granarium, after 1 day exposure period was 11.5 and 6.5 at 30 and $20^{\circ} \mathrm{C}$, respectively. While, the mortality increased after 21 days post treatment to 86.6 and $70.1 \%$ at 30 and $20^{\circ} \mathrm{C}$, respectively. At concentration $3.5 \%(\mathrm{v} / \mathrm{w})$ the mortality was 11.1 and $6.1 \%$ after 1 day exposure period and increased after 21 days post treatment to 77.7 and $61.1 \%$ at 30 and $20^{\circ} \mathrm{C}$, respectively. At concentration $3 \%(\mathrm{v} / \mathrm{w})$ the mortality was 10.5 and $5.5 \%$ after 1 day exposure and increased after 21 days exposure period to 72.2 and $45.5 \%$ post treatment at 30 and $20^{\circ} \mathrm{C}$, respectively. At concentration $2.5 \%(\mathrm{v} / \mathrm{w})$ the mortality was 7.5 and $4.5 \%$ after 1 day exposure time and increased after 21 days post treatment to 62.2 and $40.1 \%$ at 30 and $20^{\circ} \mathrm{C}$, respectively. At concentration $2 \%(\mathrm{v} / \mathrm{w})$ the mortality was 6.1 and $4.1 \%$ after 1 day exposure and increased after 21 days of the treatment to 55.1 and $33.3 \%$ at 30 and $20^{\circ} \mathrm{C}$, respectively.

\subsubsection{Worm wood oil}

The data of the effect of worm wood oil on the larvae mortality of diapausing larvae of $T$. granarium at 30 and $20 \pm 1^{\circ} \mathrm{C}$ were presented in Fig (10-14). The results showed that the mortality increased by increasing the plant oil concentration, period of exposure and temperature. At worm wood oil concentration of $4 \%(\mathrm{v} / \mathrm{w})$ the diapausing larvae mortality of $T$. granarium, after 1 day exposure period was 14.1 and 7.1 at 30 and $20^{\circ} \mathrm{C}$, respectively. While after 21 days post treatment, the mortality increased to 90.1 and $75.5 \%$ at 30 and $20^{\circ} \mathrm{C}$, respectively. At concentration $3.5 \% \quad(\mathrm{v} / \mathrm{w})$ the mortality was 11.5 and $6.5 \%$ after 1 day exposure period and increased after 21 days post treatment to 85.5 and $65.5 \%$ at 30 and $20^{\circ} \mathrm{C}$, respectively. At concentration $3 \%(\mathrm{v} / \mathrm{w})$ the mortality was 11.1 and $6.1 \%$ after 1 day exposure and increased after 21 days exposure period to 80.1 and $60.1 \%$ post treatment at 30 and $20^{\circ} \mathrm{C}$, respectively. At concentration $2.5 \%(\mathrm{v} / \mathrm{w})$ the mortality was 10.5 and $5.5 \%$ after 1 day exposure time and increased after 21 days post treatment to 75.5 and $50.1 \%$ at 30 and $20^{\circ} \mathrm{C}$, respectively. At concentration $2 \%(\mathrm{v} / \mathrm{w})$ the mortality was 8.2 and $5.1 \%$ after 1 day exposure and increased after 21days of the treatment to 70.1 and $35.5 \%$ at 30 and $20^{\circ} \mathrm{C}$, respectively.

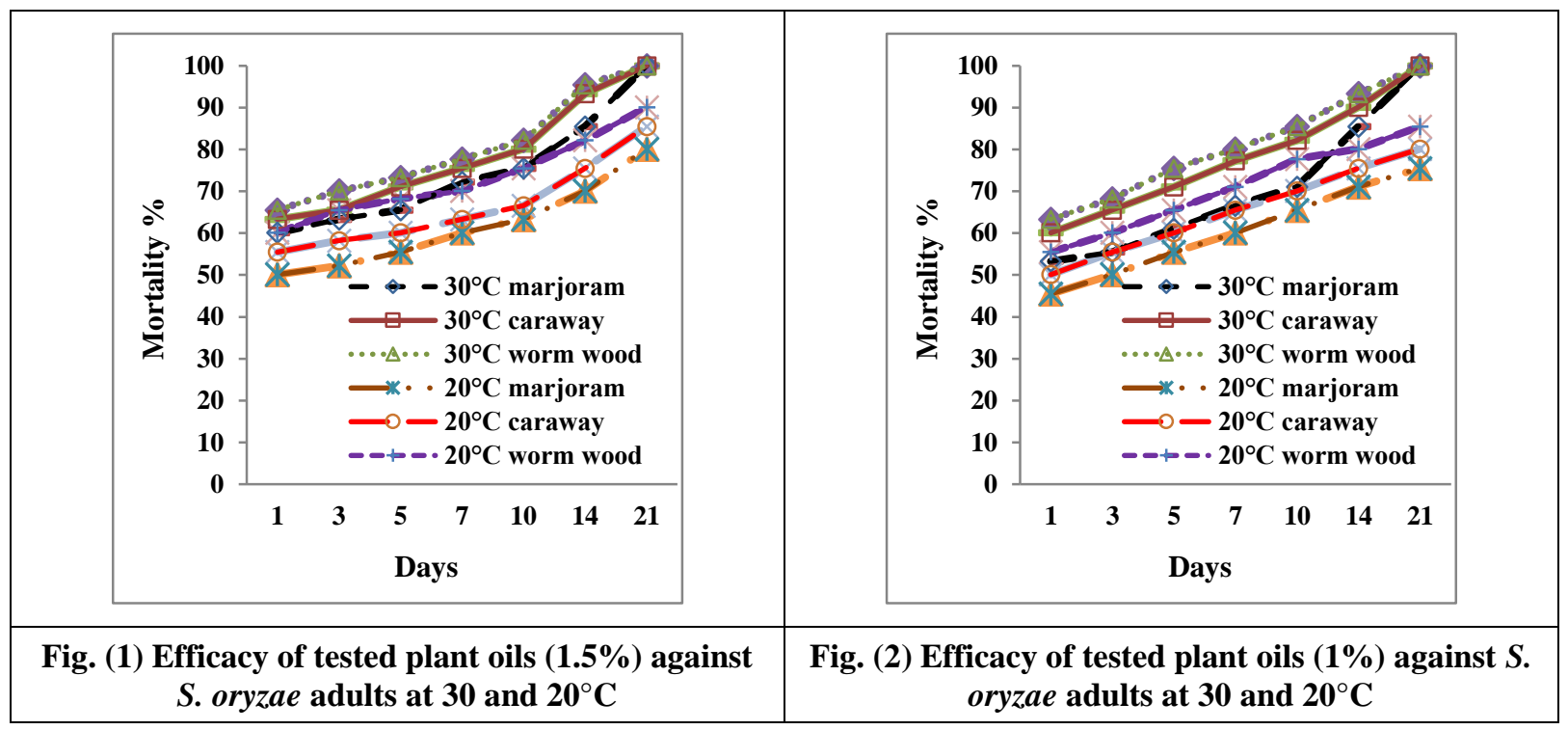




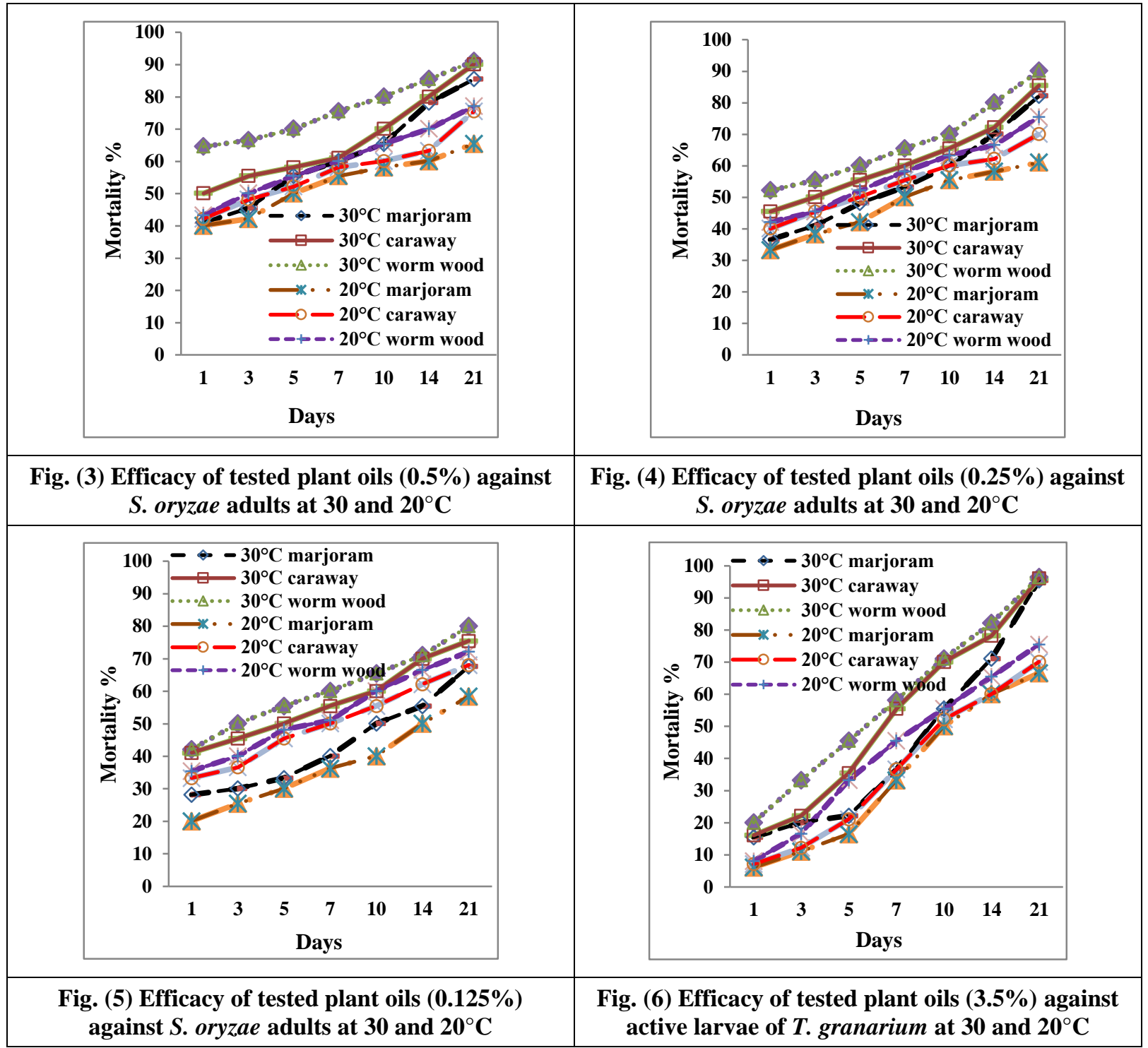

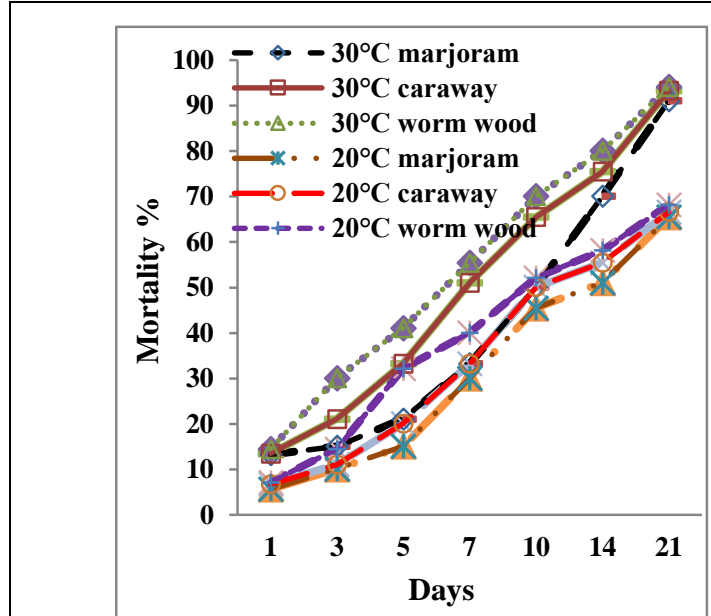

Fig. (7) Efficacy of tested plant oils (3\%) against active larvae of $T$. granarium at 30 and $20^{\circ} \mathrm{C}$

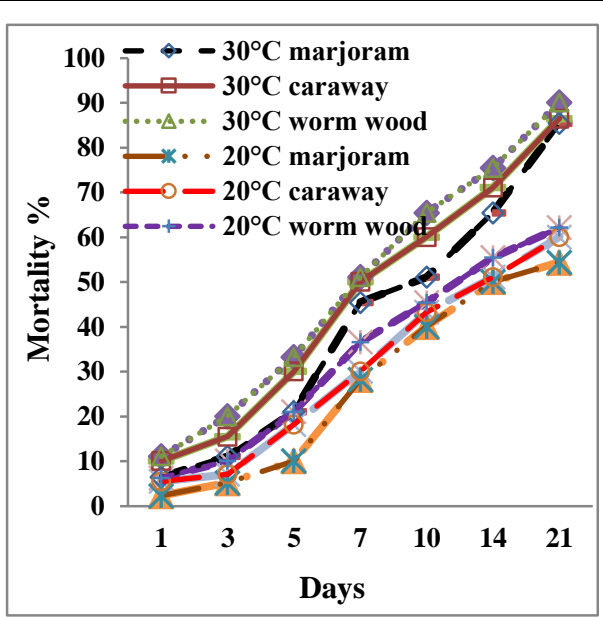

Fig. (8) Efficacy of tested plant oils (2.5\%) against active larvae of $T$. granarium at 30 and $20^{\circ} \mathrm{C}$ 


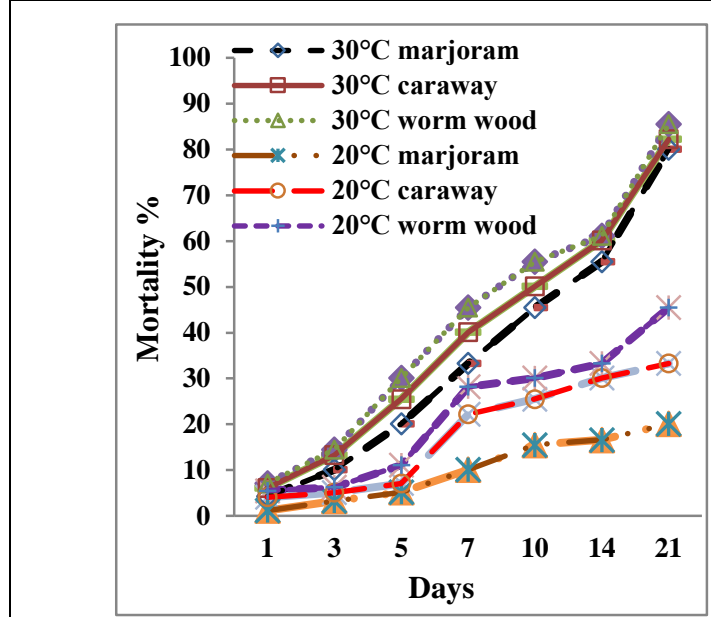

Fig. (9) Efficacy of tested plant oils (2\%) against active larvae of $T$. granarium at 30 and $20^{\circ} \mathrm{C}$

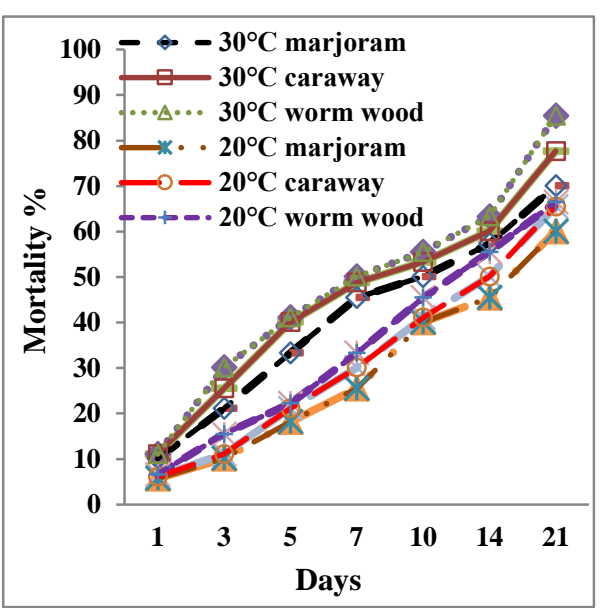

Fig. (11) Efficacy of tested plant oils (3.5\%) against diapausing larvae of $T$. granarium at 30 and $20^{\circ} \mathrm{C}$

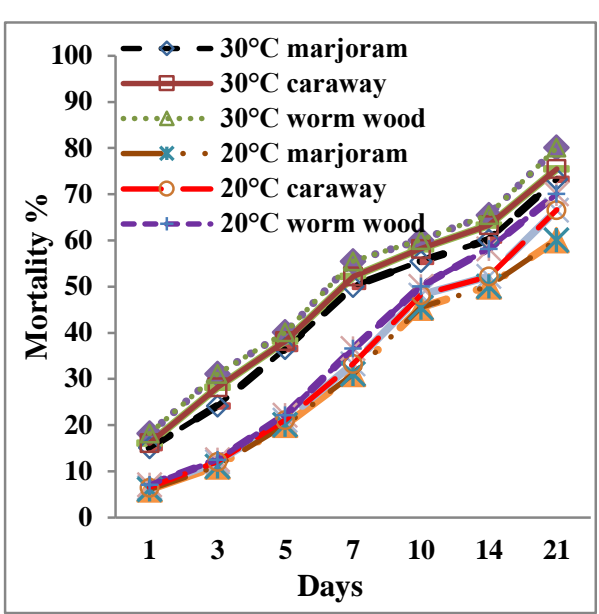

Fig. (10) Efficacy of tested plant oils (4\%) against diapausing larvae of $T$. granarium at 30 and $20^{\circ} \mathrm{C}$

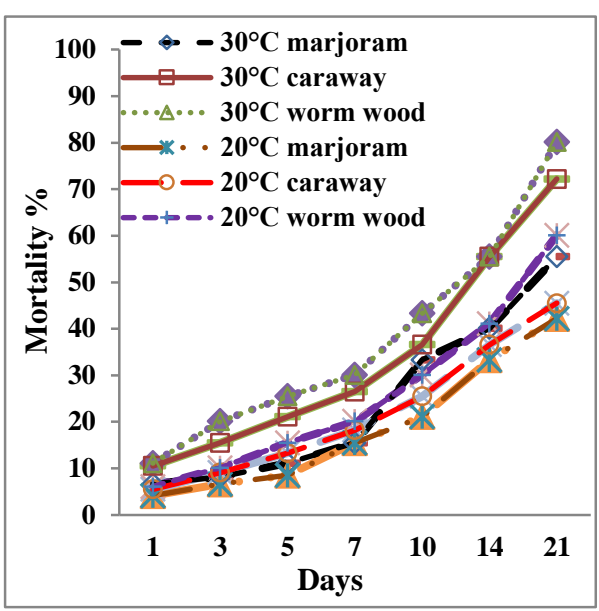

Fig. (12) Efficacy of tested plant oils (3\%) against diapausing larvae of $T$. granarium at 30 and $20^{\circ} \mathrm{C}$

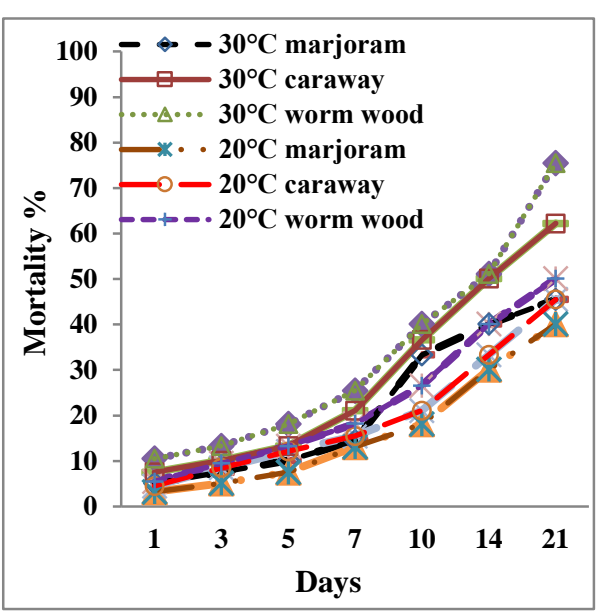

Fig. (13) Efficacy of tested plant oils (2.5\%) against diapausing larvae of $T$. granarium at 30 and $20^{\circ} \mathrm{C}$

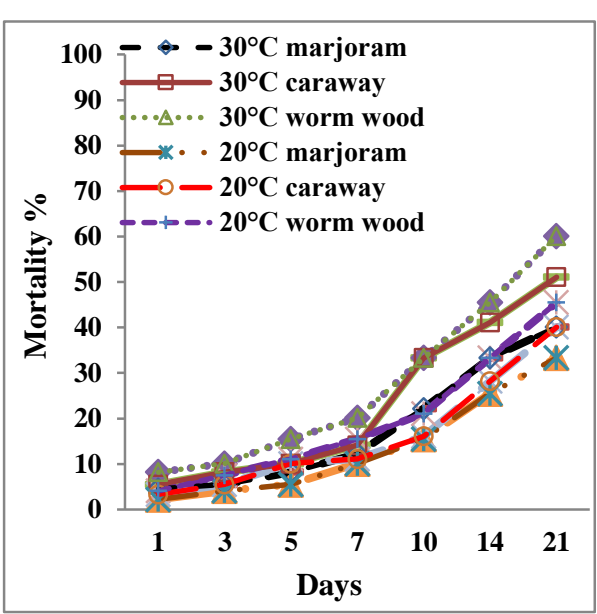

Fig. (14) Efficacy of tested plant oils (2\%) against diapausing larvae of $T$. granarium at 30 and $20^{\circ} \mathrm{C}$ 
2. Toxicity parameters of the studied plant oils against the adults of Sitophilus oryzae and the larvae of Khapera beetle Trogoderma granarium at two tested temperatures and $65 \pm 5 \%$ R.H.

\subsection{Marjoram oil}

Table (1) showed that the lethal concentrations $\left(\mathrm{LC}_{50 \mathrm{~s}}\right)$ of marjoram oil were $0.26,1.92$ and $2.27 \%$ at $30^{\circ} \mathrm{C}$ for $S$. oryzae adults (after 3 days exposure period) and active and diapausing larvae of $T$. granarium (after 14 days exposure period), respectively. While at $20^{\circ} \mathrm{C}$, these values were 0.33 ,
3.2 and $3.02 \%$ for $S$. oryzae adults and active and diapausing larvae of $T$. granarium, respectively.

2.2. Caraway oil

Table (2) revealed that the lethal concentrations $\left(\mathrm{LC}_{50 \mathrm{~s}}\right)$ of marjoram oil were $0.25,1.8$ and $2.1 \%$ at $30^{\circ} \mathrm{C}$ for $S$. oryzae adults (after 3 days exposure period) and active and diapausing larvae of $T$. granarium (after 14 days exposure period), whereas at $20^{\circ} \mathrm{C}$, they were $0.26,2.8$ and $2.9 \%$ for $S$. oryzae adults and active and diapausing larvae of $T$. granarium, respectively.

Table 1. Lethal concentration values and parameters of mortality regression line of marjoram oil on $T$. granarium larvae and $S$. oryzae adults at two tested temperatures and $65 \pm 5 \%$ R.H.

\begin{tabular}{|c|c|c|c|c|c|c|}
\hline \multirow[t]{2}{*}{$\begin{array}{c}\text { Temperature } \\
\left({ }^{\circ} \mathrm{C}\right)\end{array}$} & \multirow[t]{2}{*}{$\begin{array}{c}\text { Insect } \\
\text { Species }\end{array}$} & \multirow[t]{2}{*}{ Stage } & \multicolumn{2}{|c|}{$\begin{array}{c}\text { Lethal concentrations (v/w \%)of } \\
\text { marjoram }^{5} \text { oil and Their } 95 \% \\
\text { Confidence Limits }\end{array}$} & \multirow[t]{2}{*}{$\begin{array}{l}\text { Slope } \\
\pm \text { SD }^{1}\end{array}$} & \multirow[t]{2}{*}{$\mathbf{R}^{4}$} \\
\hline & & & $\mathrm{LC}_{50}$ & $\mathrm{LC}_{90}$ & & \\
\hline \multirow{3}{*}{20} & \multirow[b]{2}{*}{ T.granarium } & $\mathbf{A} \mathbf{L}^{2}$ & $\begin{array}{c}3.22 \\
(2.96-3.70)\end{array}$ & $\begin{array}{c}7.08 \\
(5.40-12.96)\end{array}$ & $3.7 \pm 0.73$ & 0.99 \\
\hline & & $\mathbf{D L}^{3}$ & $\begin{array}{c}3.02 \\
(2.60-3.40)\end{array}$ & $\begin{array}{c}9.35 \\
(6.90-20.90)\end{array}$ & $2.6 \pm 0.54$ & 0.97 \\
\hline & S.oryzae & Adult & $\begin{array}{c}0.33 \\
(0.19-0.48)\end{array}$ & $\begin{array}{c}1.20 \\
(0.90-1.70)\end{array}$ & $1.9 \pm 0.18$ & 0.91 \\
\hline \multirow{3}{*}{30} & \multirow[b]{2}{*}{ T.granarium } & $\mathbf{A} \mathbf{L}^{2}$ & $\begin{array}{c}1.92 \\
(1.64-2.10)\end{array}$ & $\begin{array}{c}3.87 \\
(3.50-4.50)\end{array}$ & $4.5 \pm 0.75$ & 0.95 \\
\hline & & $\mathbf{D L}^{3}$ & $\begin{array}{c}2.27 \\
(1.20-4.50)\end{array}$ & $\begin{array}{c}4.50 \\
(2.10-6.30)\end{array}$ & $4.2 \pm 0.61$ & 0.98 \\
\hline & S.oryzae & Adult & $\begin{array}{c}0.26 \\
(0.22-0.31)\end{array}$ & $\begin{array}{c}1.50 \\
(1.10-3.80)\end{array}$ & $1.9 \pm 0.17$ & 0.90 \\
\hline
\end{tabular}

1: Standard deviation $\quad$ 2: Active larva $\quad$ 3: Diapausing larva4: Correlation coefficient of
regression line5: Mortality was recorded after 14 days of treatment for active and diapausing larvae of $T$. granarium and 3 days for $S$. oryzae adults

Table 2. Lethal concentrations values and parameters of mortality regression line of caraway oil on $T$. granarium larvae and S. oryzae adults at two tested temperatures and $65 \pm 5 \%$ R.H.

\begin{tabular}{|c|c|c|c|c|c|c|}
\hline \multirow[t]{2}{*}{$\begin{array}{l}\text { Temperature } \\
\left({ }^{\circ} \mathrm{C}\right)\end{array}$} & \multirow[t]{2}{*}{$\begin{array}{c}\text { Insect } \\
\text { Species }\end{array}$} & \multirow[t]{2}{*}{ Stage } & \multicolumn{2}{|c|}{$\begin{array}{c}\text { Lethal concentrations(v/w\%)of } \\
\text { caraway }{ }^{5} \text { oil and Their } 95 \% \\
\text { Confidence Limits }\end{array}$} & \multirow[t]{2}{*}{$\begin{array}{l}\text { Slope } \\
\pm \text { SD }^{1}\end{array}$} & \multirow[t]{2}{*}{$\mathbf{R}^{4}$} \\
\hline & & & $\mathrm{LC}_{50}$ & $\mathrm{LC}_{90}$ & & \\
\hline \multirow{3}{*}{20} & \multirow{2}{*}{ T.granarium } & $\mathbf{A} \mathbf{L}^{2}$ & $\begin{array}{c}2.85 \\
(2.55-3.31)\end{array}$ & $\begin{array}{c}8.50 \\
(5.70-28.60)\end{array}$ & $2.0 \pm 0.70$ & 0.99 \\
\hline & & $\mathbf{D L}^{3}$ & $\begin{array}{c}2.92 \\
(2.70-3.19)\end{array}$ & $\begin{array}{c}7.50 \\
(5.80-12.20)\end{array}$ & $3.2 \pm 0.55$ & 0.99 \\
\hline & S.oryzae & Adult & $\begin{array}{c}0.26 \\
(0.20-0.30)\end{array}$ & $\begin{array}{c}1.40 \\
(1.06-2.06)\end{array}$ & $1.7 \pm .0 .17$ & 0.90 \\
\hline \multirow{3}{*}{30} & \multirow{2}{*}{ T.granarium } & $\mathbf{A} \mathbf{L}^{2}$ & $\begin{array}{c}1.80 \\
(1.50-2.40)\end{array}$ & $\begin{array}{c}3.48 \\
(3.15-4.17)\end{array}$ & $1.9 \pm 0.18$ & 0.95 \\
\hline & & $\mathbf{D L}^{3}$ & $\begin{array}{c}2.10 \\
(1.80-2.20)\end{array}$ & $\begin{array}{c}5.12 \\
(4.25-7.80)\end{array}$ & $2.8 \pm 0.70$ & 0.96 \\
\hline & S.oryzae & Adult & $\begin{array}{c}0.25 \\
(0.22-0.31)\end{array}$ & $\begin{array}{c}1.2 \\
(0.90-1.70)\end{array}$ & $1.9 \pm 0.18$ & 0.91 \\
\hline
\end{tabular}

1: Standard deviation 2: Active larva 3: Diapausing larva

4: Correlation coefficient of regression line 5: Mortality was recorded after 14 days of treatment for active and diapausing larvae of $T$. granarium and 3 days for $S$. oryzae adults 


\subsection{Worm wood oil}

Table (3) exhibited that the lethal concentrations $\left(\mathrm{LC}_{50 \mathrm{~s}}\right)$ of marjoram oil were $0.21,1.5$ and $2.1 \%$ at $30^{\circ} \mathrm{C}$ for $S$. oryzae adults (after 3 days exposure period) and active and diapausing larvae of $T$. granarium (after 14 days exposure period), respectively. At $20^{\circ} \mathrm{C}, \mathrm{LC}_{50 \mathrm{~s}}$ were $0.23,2.4$ and 2.9 $\%$ for $S$. oryzae adults and active and diapausing larvae of $T$. granarium, respectively.

The present results are in accordance with the results of several authors, who concluded that mortality of tested insects increased with increase in concentration at maximum exposure period (Ellakwah et al., 2002; Boffet al., 2006;Azab, 2015). The data indicated clearly that $S$. oryzae adults were the most sensitive to the three tested oils, whereas the diapausing larvae of $T$. granarium were the least sensitive to the plant oils under study. These findings agree with the results with other investigations (Padin, 2000; Wawrzyniak and Blazejewska 2002; Sahafet al., 2008)

Table 3. Lethal concentrations values and parameters of mortality regression line of worm wood oil on T.granarium larvae and S. oryzae adults at two tested temperatures and $65 \pm 5 \%$ R.H.

\begin{tabular}{|c|c|c|c|c|c|c|}
\hline \multirow[t]{2}{*}{$\begin{array}{l}\text { Temperature } \\
\left({ }^{\circ} \mathrm{C}\right)\end{array}$} & \multirow[t]{2}{*}{$\begin{array}{c}\text { Insect } \\
\text { Species }\end{array}$} & \multirow[t]{2}{*}{ Stage } & \multicolumn{2}{|c|}{$\begin{array}{l}\text { Lethal concentrations(v/w \%)of } \\
\text { wormwood }^{5} \text { oil and Their } 95 \% \\
\text { Confidence Limits }\end{array}$} & \multirow[t]{2}{*}{$\begin{array}{l}\text { Slope } \\
\pm \text { SD }^{1}\end{array}$} & \multirow[t]{2}{*}{$\mathbf{R}^{4}$} \\
\hline & & & $\mathbf{L C}_{50}$ & $\begin{array}{l}\mathrm{LC}_{90} \\
\end{array}$ & & \\
\hline \multirow{3}{*}{20} & \multirow{2}{*}{ T.granarium } & $\mathbf{A} \mathbf{L}^{2}$ & $\begin{array}{c}2.41 \\
(1.85-2.60)\end{array}$ & $\begin{array}{c}9.40 \\
(5.04-22.15)\end{array}$ & $2.6 \pm 0.70$ & 0.97 \\
\hline & & $\mathbf{D L}^{3}$ & $\begin{array}{c}2.90 \\
(2.7-3.07)\end{array}$ & $\begin{array}{c}5.30 \\
(4.70-6.40)\end{array}$ & $4.9 \pm 0.57$ & 0.96 \\
\hline & S. oryzae & Adult & $\begin{array}{c}0.21 \\
(0.16-.25)\end{array}$ & $\begin{array}{c}1.13 \\
(0.89-1.50)\end{array}$ & $1.8 \pm 0.18$ & 0.97 \\
\hline \multirow{3}{*}{30} & \multirow{2}{*}{ T. granarium } & $\mathbf{A} \mathbf{L}^{2}$ & $\begin{array}{c}2.18 \\
(1.9-2.40)\end{array}$ & $\begin{array}{c}5.12 \\
(4.30-6.83)\end{array}$ & $2.6 \pm 0.70$ & 0.97 \\
\hline & & $\mathbf{D L}^{3}$ & $\begin{array}{c}2.31 \\
(1.8-2.6)\end{array}$ & $\begin{array}{c}7.19 \\
(0.04-221)\end{array}$ & $3.5 \pm 0.65$ & 0.97 \\
\hline & S. oryzae & Adult & $\begin{array}{c}0.23 \\
(0.09-0.30)\end{array}$ & $\begin{array}{c}1.10 \\
(0.90-5.00)\end{array}$ & $1.9 \pm 0.17$ & 0.87 \\
\hline
\end{tabular}
2: Active larva 3: Diapausing larva

4: Correlation coefficient of regression line 5: Mortality was recorded after 14 days of treatment for active and diapausing larvae of $T$. granarium and 3 days for $S$. oryza $e$ adults

On the other hand, at $30^{\circ} \mathrm{C}$ the three investigated oils had relatively equal toxicity to $S$. oryzae adults, while at $20^{\circ} \mathrm{C}$ the worm wood oil was the most toxic for all tested insects, however in case of active and diapausing larvae of $T$. granarium, caraway oil was the most toxic at $30^{\circ} \mathrm{C}$. Where, the toxicity of plant oils for stored-product insects was influenced by their chemical composition (Lee et al., 2001). Moreover, the diverse effects of the two tested temperatures were observed on oil toxicity and the insect species. On the contrary,Fang and subramanyam (2003) evaluated the activity of spinosad against $R$. dominicais not affected by wheat temperature. Also, some authors reported that plant oils possess similar type of activity against pests (Maggi et al.,2005;Zamani et al.,2010). Plant oils are generally broad spectrum due to the presence of several active ingredients that may operate through various modes of action (Chiassonet al., 2004).

\section{Conclusion}

Therefore the findings of present study suggested that plant oils of marjoram, caraway and worm wood may be potentially used as eco- friendly pest controlagents against insect pests of stored products.

\section{References}

Azab, M. M. (2015): Combined activity of spinosyns A, D, J and L on two stored product insects. Egypt. Acad. J. Biolog. Sci., 7(1): 7180.

Benhalima, H., Chaudhry, M.Q. Mills, K.A. and Price, N.R. (2004): Phosphine resistance in stored-product insects collected from various grain storage facilities in Morocco. J. Stored. Prod. Res. 40:241-249.

Boff, M.I.C.;Sartoarid, V.andBogo, A. (2006): Effect of extracts of Piper nigrumL. on the bean weevil, Acanthosceli desobtectus(Say). RevistaBrasileria de Armazenamento, 31: 17-22.

Bughio, F.M. and W ilkins, R.M. (2004): Influence of malathion resistance status on survival and 
growth of Tribolium castaneum (Coleoptera: Tenebrionidae), when fed on flour from insect resistant and susceptible grain rice cultivars. J. Stored. Prod. Res.40:65-75.

Chiasson, H.;Vincent, C. and Bostanian N.J. (2004): Insecticidal properties of a Chenopodium-based botanical. J. Econ .Entomol., 97 (4): 1378-1383.

Darwish, A.A. (1992): Laboratory studies on toxicity and effect of some plant extracts as stored product protectants.Egypt. J. Appl. Sci., 7(12):138-147.

Dubey N.; Srivastava, B.and Kumar, A. (2008): Current status of plant products as botanical pesticides in storage pest management. J. Biopest; 1(2):182-186.

El-Lakwah, F.A.; Omnia M.Khaled and Darwish, A.A (1992): Toxic effect of pulverized black pepper (PippernigrumL.) on some stored product insects. Annals Agric. Sc., Moshtohor, 30 (4): 2049-2057.

El -Lakwah,F.A; Omnia M.Khaled and Darwish,A.A.(1993): Toxic effect of fenugreek( Trigonella foenumgroecnum L.) and fennel (Foentcumvulgare L.) extract alone and in mixture with two organophosphorus insecticides against Rhizopertha dominica (F). Annals Agric. Sc., Moshtohor,31(1):605-615.

El-Lakwah, F.A.;Mohamed, R.A. and Omnia M.Khaled (1994): Toxic effect of chinaberry tree (Meliaazedrach )on Rhizopertha dominica $(\mathrm{F})$. Annals Agric.Sc.,Moshtohor,32(4):2195-2204.

El-lakwah, F.A.; Omnia M. KhaledandHalawa, Z.A.(1996): Effect of modified atmosphere of more than $99 \%$ nitrogen or enriched with carbon dioxide on mortality of some stored product insects, seed germination, chlorophyll and carotene contents of certain crop seed lings. Annals of Agric. Sc.Moshtohor, 34(4): 1869 - 1877.

El-Lakwah, F.A.; Darwish, A.Aand Mohamed, R.A. (1997): Efficacy of a modified atmosphere of around $1 \%$ oxygen plus $99 \%$ nitrogen on some stored product insects. Annals Agric. Sc., Moshtohor, 35 (1): 549-557.

El-Lakwah, F.A.; El-Kashlan, I.H.; Abd El-Aziz, A.E.and Halawa, Z.A. (2002): Reliable potencies of some grain protectant and their combinations with carbon dioxide against the Rice weevil, Sitophilusoryzae(L.) Annals Agric. Sc., Moshtohor, 40(2):1295-1308.

Fang, L. and Subramanyam, B. (2003): Activity of spinosad against adults of Rhyzoperth adominica(F.) (Coleoptera: Bostrychidae) is not affected by wheat temperature and moisture. J. Kansas Entomol. Soc., 76: 529-532.

Finney, D.J. (1971): Probit analysis. 3rd.Eddn, Cambridge University press: Cambridge, U.K. 318 pp.

Halawa, Z.A. (1998); Evaluation of acetone and petroleum ether extracts of Lantana camara leaves and Delonixregia seeds aganists the cowpea beetle-Callosobruchus maculates (F)Annals Agric.Sc. Moshtohor,36(4):2651-2669.

Hansen, L.S.and Jensen, K.M.V. (2002): Effect of temperature on parasitism and host-feeding of Trichogramma turkestanica (Hymenoptera: Trichogrammatidae) on Ephestiakuehniella (Lepidoptera: Pyralidae). J Econ.Entomol.,95:50-56.

Hassan, R.S.;Mikhaiel, A.A.andSileem,Th.M. (2013): Integration of Gamma Irradiation and Some Botanical oils to Protect Cowpea and Chickpea Seeds from Infestation with the Bruchid Beetle, Callosobruchus maculatusJ Stored Prod Res, 50:357-364.

Hernandez, R. L.; Pajaro, N. C.; Caballero, K. G.; Elena Stashenko and Olivero, J. V. (2015): Essential oils from plants of the genus Cymbopogon as natural insecticides to control stored product pests. J. Stored. Prod. Res., 62:81-83.

Jacobson, M. (1982): Plants, insects, and man-their interrelationships. Econ. Bot., 36(3):346- 354.

Jaipal,S.; Singh, Z. and Malik, O.P. (1984): Insecticidal activity of various neem leaf extracts on Rhizopertha dominica as stored grain. Neem. New SI., 1:35-36.

Javier, P.A.; Morallo - Rejesus and Rejesus, B.(1986): Insecticidal activity of black pepper (Piper nigerum L.) extracts. Philippine- Entomologist 6(5): 517-525.

Lee, S.E.; Lee,B.H.; Choi, W.S.;Park,B.S.; Kim,J.G. and Campbell,B.C. (2001): Fumigant toxicity of volatile natural products from Korean spices and medicinal plants towards the rice weevil, Sitophilusoryzae (L). Pest Manag. Sci., 57:548-553.

Maggi, M.E. ;Mangeand, A.;Carpinella, M.C., Ferrayoli, G.C.;Valladars, G.R.and Palacios, S.M. (2005): Laboratory evaluation of Artemisia annuaL. Extract and artemisinin activity against Epilachnapae mulaand Spodoptera eridania,J. Chem. Ecol., 31:1527-1536.

Noack, S. and Reichmuth, C.H. (1978): Einrechnerisches Verfahrenzur Bestimmung von beliebigenDosiswerteneinesWirkstoffesausempirischen Dosis-Wirkungs-Daten. Mitt.Biol. BundesanstaltfuerL and u. Forts-Wirtschaft, Berlin-Dahlem, Heft, 185: 149.

Padin, S.; Ringuelet, J. A.; Bello, D.; Cerimele, E. L.; Re, M. S.and Henning, C. P.(2000): Toxicology and repellent activity of essential oils on Sitophilus oryzae L. and Tribolium castaneum Herbst,J. Herbs Spices Med. Plants, 7(4):67-73.

Sahaf, B. Z.; Moharramipour, S. and Meshkatalsadat, M.H. (2008): Fumigant toxicity of essential oil from Vitex pseudo-negundo against Tribolium castaneum (Herbst) and Sitophilusoryzae (L.), J. Asia Pac. Entomol., 11: 175-179.

Sighamony, S., Anees, I., Chandrakala, T.andOsmani, Z. (1986): Efficacy of certain indigenous plant products as grain protectants against Sitophilus oryzae (L.) and Rhizopertha dominica (F.). J. Stored. Prod. Res. 22: 21 $-23$.

$\mathrm{Su}$, H.C.F.(1985): Laboratory evaluation of dill seed extract in reducing infestation of rice weevil in stored wheat. J. Ent.Sci., 24: 317-320.

Su, H.C.F. (1989): Laboratory study on effects of Anethum graveolens seeds on four species of stored product insects. J. Econ. Entomol. 78 (2): 451-453.

Wawrzyniak, M. and Blazejewska, A. (2002): Estimation of influence of essential oil of Foeniculumca pillaceumGilib and Coriandrum sativum L. on the fecundity of Sitophilusoryzae L. [Polish]. Progress in Plant Protection. 42(2):644-646. 
Yadav, T.D. (1984): Efficacy of neemAzadirachta indigo A.Juss- Kernel powder as seedtreatment against pulse beetles. Neem News 1, 1: 13-15.

Zamani S., Sendi J.J.and Ghadamyari M. (2010): Effect of Artemisia annuaL. (Asterales: Asteraceae) essential oil onmortality, Development, Reproduction and Energyreserves of PlodiaInter punctella (Hubner). (Lepidoptera:Pyrallidae). J. BiofertilBiopestic, 2:105.

\section{فاعلية بعض الزيوت النباتية ضد اثثين من حشرات المواد المخزونة}

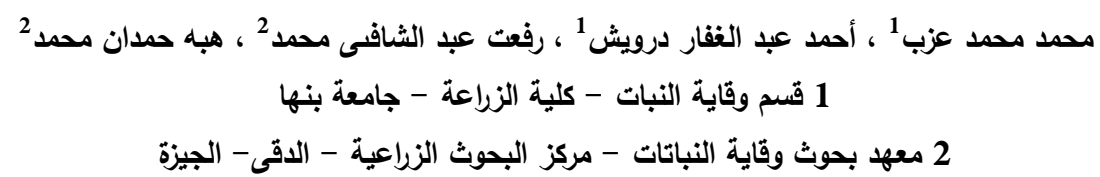

أجرى هذا البحث لدراسة الثأثير الإبادى للزيوت النباتية للبردقش والكراوية والثثيح على الحشرة الكاملة لسوسة الأرز واليرقات النشطة والساكنة

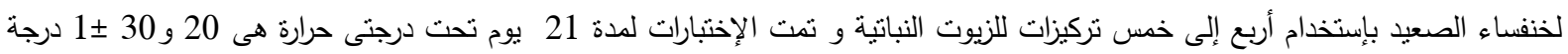

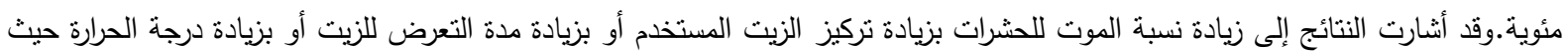

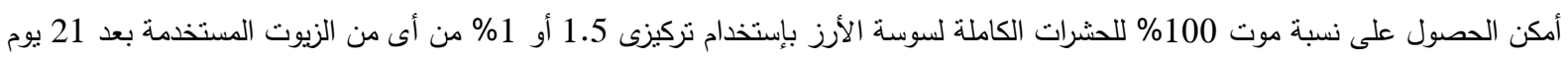

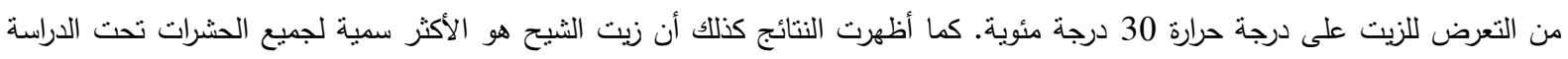

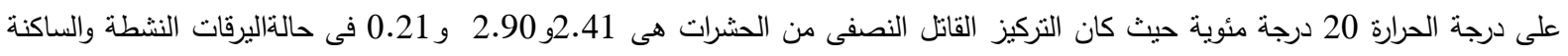

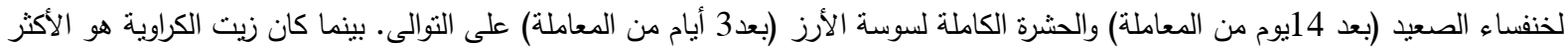

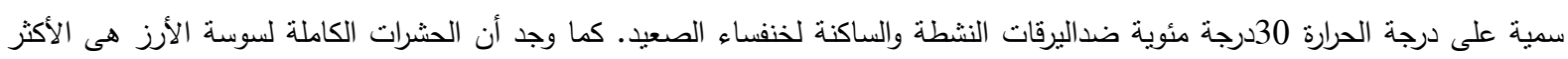

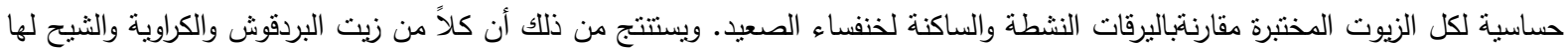
تأثثر سام ضد كل من حشرتى سوسة الأرزو خنفساء الصعيد. 